[6] Yu, X. R., Zhou, L., Zhang, J., Yu, H., Gao, D. R., Zhang, B. Q. et. al. (2015). Comparison of Structural Development and Biochemical Accumulation of Waxy and Non-waxy Wheat Caryopses. Cereal Research Communications, 43 (2), 307-317. doi: http://doi.org/10.1556/crc.2014.0038

[7] Rybalka, O. I. (2011). Yakist pshenytsi ta yii polipshennia. Kyiv: Lohos, 495.

[8] Lekarstvennoe rastenie topinambur. Available at: http://www.malva-topinambur.com

[9] Lebedenko, T. Ye., Pshenyshniuk, H. F., Sokolova, N. Yu. (2014). Tekhnolohiia khlibopekarskoho vyrobnytstva. Odessa: Osvita Ukrainy, 392.

[10] Izmeritel' deformatsii kleykoviny IDK-7 (2014). Odessa. Available at: http://altairplus.com.ua/ files/files/Pass_uDk7.pdf

[11] AACC International Approved Methods. Available at: http://methods.aaccnet.org/summaries/54-10-01.aspx

[12] Iorhachova, K. H., Makarova, O. V., Hordiienko, L. V., Korkach, H. V.; Iorhachova, K. H. (Ed.) (2011). Tekhnolohiia kondyterskoho vyrobnytstva. Praktykum. Odesa, 208.

[13] Yorhacheva, E. H., Makarova, O. V., Khvostenko, E. V., Hromova, A. V. (2011). Vliyanie inulinsoderzhashhego syr'ya na protsess brozheniya polufabrikatov dlya galet. Kharchova nauka i tekhnolohiia, 1, 6-9.

[14] Iorgachova, K., Makarova, O., Khvostenko, K. (2016). The rationale of selecting pastries to be made with waxy wheat flour. Eastern-European Journal of Enterprise Technologies, 2 (11 (80)), 12-19. doi: http://doi.org/10.15587/1729-4061.2016.65756

\title{
IINFLUENCE OF MAIN TECHNOLOGICAL PARAMETERS OF DRYING ON QUALITY OF BAGASSE FROM CARROT AND BEET
}

\author{
Aziz Sardarov
}

Department of Processes, apparatus and automation of food production Kharkiv State University of Food Technology and Trade 333 Klochkivska str., Kharkiv, Ukraine, 61051 sardarov.aziz@gmail.com

\section{Olga Mayak}

Department of processes, apparatus and automation of food productions Kharkiv State University of Food Technology and Trade 333 Klochkivska str., Kharkiv, Ukraine, 61051

\section{Andrey Shevchenko}

Department of Processes, apparatus and automation of food production Kharkiv State University of Food Technology and Trade 333 Klochkivska str., Kharkiv, Ukraine, 61051

\section{Svitlana Prasol}

Department of Processes, apparatus and automation of food production Kharkiv State University of Food Technology and Trade 333 Klochkivska str., Kharkiv, Ukraine, 61051

\section{Gennadiy Shershnev}

Department of Processes, apparatus and automation of food production Kharkiv State University of Food Technology and Trade 333 Klochkivska str., Kharkiv, Ukraine, 61051 gengenyth@gmail.com 


\begin{abstract}
The work studies the drying process of vegetable bagasse, namely of carrot and beet. There is studied the moisture content kinetics of vegetable bagasse and determined the dependence of the process duration on main technological parameters in the work of a vibration vacuum dryer, namely, an amplitude and frequency. There were studied quality parameters of obtained concentrated products, namely the colorimetric estimation of dried bagasse of carrot and beet. Based on obtained results of the study, it was established, that the use of vibration in the process of drying bagasse favors conservation and formation of colorimetric characteristics of a dried product. Determined color characteristics gave a possibility to establish, that at thermal processing it is very important to decrease the drying process duration and temperature. Research data proved prospects of producing concentrated products, namely, dried bagasse of carrot and beet by the offered method. It allows to regulate quality parameters of a ready product: color, brightness, consistence, viscosity and physical-chemical properties. Obtained concentrated products are characterized with high organoleptic indices, food value. This product may be used in the wide spectrum of food industry, such as, for example: juice supplement, stuff for confectionary mass, filling for confectionary products, as biological supplement for healthy nutrition.
\end{abstract}

Keywords: drying modes, concentrated products, vibration driers, colorimetric estimation, vegetable bagasse.

DOI: $10.21303 / 2504-5695.2018 .00732$

(C) Aziz Sardarov, Olga Mayak, Andrey Shevchenko, Svitlana Prasol, Gennadiy Shershnev

\title{
1. Introduction
}

The solution of problems of developing new processing technologies for vegetable raw materials is inseparably connected with the improvement of the apparatus design and creation of new apparatuses that reach the high intensity of the heat and mass exchange process [1].

The aim of work [2] was to study the influence of drying conditions on red beet in the aspect of betaine dispersion and polyphenol, change of the microstructure. The strong thermal shock, provided by convection at $60^{\circ} \mathrm{C}$, then microwave power $315 \mathrm{~W} / 9 \mathrm{~min}$ result in better conservation of the bioactive compounds content, comparing with convection at 50,60 and $70{ }^{\circ} \mathrm{C}$. The results demonstrated that combined drying methods resulted in the essential conservation of the phytochemical content, comparing with traditional methods, but need the essential development in the practical realization of the offered drying methods.

Work [3] presents the results of studying pectin-containing vegetable raw materials. The optimal parameters of a drying agent that guarantee the high conservation degree of pectin and biological substances were established. But the influence of drying parameters on the outlook of products was not studied.

Work [4] determines the kinetics of vacuum drying, thermal history and quality kinetics of vegetable composition. A set of parameters was established for each formulation, and satisfactory experimental data were obtained. As a result of the conducted studies, there was recommended vacuum drying at $70{ }^{\circ} \mathrm{C}$. The degradation mode of ascorbic acid was determined, depending on the tray temperature that is not exact, because the degradation process takes place within a product layer, and heating - through a tray wall, so a crust forms on the surface that decelerates the dehydration process.

Work [5] elaborated the system approach for choosing correspondent drying parameters. This approach can provide simple and comprehensive instructions for choosing suitable working parameters for any drying machine with a pseudo-liquefied layer with a possibility of the maximal permeability for drying vegetable raw materials with the high level of admixtures. These studies are directed on choosing drying parameters, based on the process duration, but don't include the study of a ready product's quality.

Work [6] formulates the conceptual principle of creation of the effective drying method and equipment for its realization. Beet bagasse drying at different modes was substantiated.

Work [7] studies carrot bagasse drying at infrared energy supply. Carrot bagasse without preliminary processing, carrot bassage from raw materials after preliminary thermal processing - blanching by water during 10 minutes at $80-83{ }^{\circ} \mathrm{C}$ and blanching by acute steam during $3-5$ min were used as samples. Curves of bagasse drying kinetics were formed by the series of conducted studies.

For realizing the raw material drying process, there was used the equipment applying the vacuum technology that allows to increase the boiling temperature in a drying chamber essentially (to $45^{\circ} \mathrm{C}$ ), that gives a possibility to conserve thermolabile substances and as a result to increase 
the quality and food value of obtained products. At the same time for intensifying the dehydration process, there is offered to use low-frequency vibrations of trays that a product is placed on.

The aim of the work is to study the influence of technological parameters of the drying process of vegetable bagasse on quality characteristics of a dried product that allows to regulate the main organoleptic parameters of it, namely color, taste, structure (plasticity, solidity, porosity and so on).

\section{Materials and methods of studying mass exchange and determining colorimetric charac- teristics of obtained concentrated products}

\section{1. Materials, used in the study}

The main material, used in the studies, was bagasse, obtained after dividing the raw materials (carrot, beet) in liquid (juice) and solid (bagasse) phases. The moisture content in bagasse, depending on the division method, varied within $55 \ldots 60 \%$. In the drying process the final content of moisture in dried bagasse was equal to $10 \%$. The carrot variety "Carrotel" and beet "Bordo 237" were chosen for the experiments. Completely ripe fruits were chosen. Bagasse sizes after division varied in the diapason from $0,01 \mathrm{~m}$ to $0,03 \mathrm{~m}$, and dried from $0,002 \mathrm{~m}$ to $0,005 \mathrm{~m}$.

\section{2. Method of studying the process of vibro-vacuum drying of vegetable bagasse}

For providing the continuous uninterrupted processing of vegetable bagasse and also for improving the quality of ready products, there was developed a vibration vacuum drier of uninterrupted action. The method of the study is described in work [8]. Drying is realized as following: bagasse is uploaded by rations through a measuring pocket on perforated trays, fixed on a shaft, connected to a generator of vibration, and a dried product accumulates up to the given mass and is taken out through the measuring pocket. Dried bagasse is weighed on measuring scales.

For choosing optimal modes of vibro-processing, there was calculated the working mode coefficient $\mathrm{C}$ [9] that indicates the ratio of vertical acceleration, transmitted by vibration to a particle, to the gravity force acceleration. The calculated coefficient gives a possibility to choose an amplitude and frequency of vibrations, solving energy saving problems, so they are chosen in such a way that the material shifts, but the state doesn't transform in vibro-flowing one $(\mathrm{C}>3)$. The directed shift of the material is created only at $\mathrm{C}>1$, and at $1<\mathrm{C}<3$ the dispersed system transforms in the vibro-boiling state (particles tear off from each other at shifting).

\subsection{Method of determining colorimetric characteristics of dried carrot and beet bagasse}

One of problems at storage and processing of food products of natural raw materials is a change of quality properties, first of all, color. It conditions a necessity of analyzing methods of determining color properties of raw materials for searching a cheaper express-method [10].

Color characteristics of samples were determined by CIE XYZ method, based on a tricolorimetric model of color. Blue, green and red are base colors, other ones form by mixing the base colors in correspondent ratios, determined by color coordinates $\mathrm{x}, \mathrm{y} \mathrm{z}$. If the sum is $1: \mathrm{x}+\mathrm{y}+\mathrm{z}=1$, the color is white. At that the color surface is perceived in its specific color due to reflection of the light with a certain length, all last waves are absorbed. Using this method, we can get reflection spectrums for opaque substances and materials by measuring the spectrum coefficient of diffusion reflection $\mathrm{R}_{\lambda}[11]$.

\section{1. Study of kinetics of moisture content depending on drying parameters of vegetable} bagasse

For determining the influence of main drying technological parameters, namely, an amplitude and frequency of vibration and also a pressure in the apparatus on a speed of the process, there were conducted the experiments of kinetics of the moisture content of dried vegetable bogasse.

The results of the experimental studies of kinetics of the moisture content at drying vegetable bogasse depending on drying parameters are presented on Fig. 2, 3, the experiments were conducted under conditions of different technological drying parameters, indicated in Table 1, chosen by the described methods in section 2.2 . 
Table 1

Drying modes for vegetable bogasse

\begin{tabular}{cccc}
\hline Name & Amplitude, $\mathbf{m}$ & Frequency, $\mathbf{H z}$ & Pressure, $\mathbf{M P a}$ \\
\hline Mode 1 & 0 & 0 & 0,09 \\
Mode 2 & 0,005 & 6 & 0,09 \\
Mode 3 & 0,005 & 8 & 0,09
\end{tabular}

Fig. 1. presents the results of the experiment of kinetics of the moisture content at drying carrot bogasse at different drying parameters. Thus, drying bogasse at mode 3 continues 82 min and at mode 2 it continues $96 \mathrm{~min}$, but its duration at mode 1 is 118 min that is by $45 \%$ more than at mode 3 .

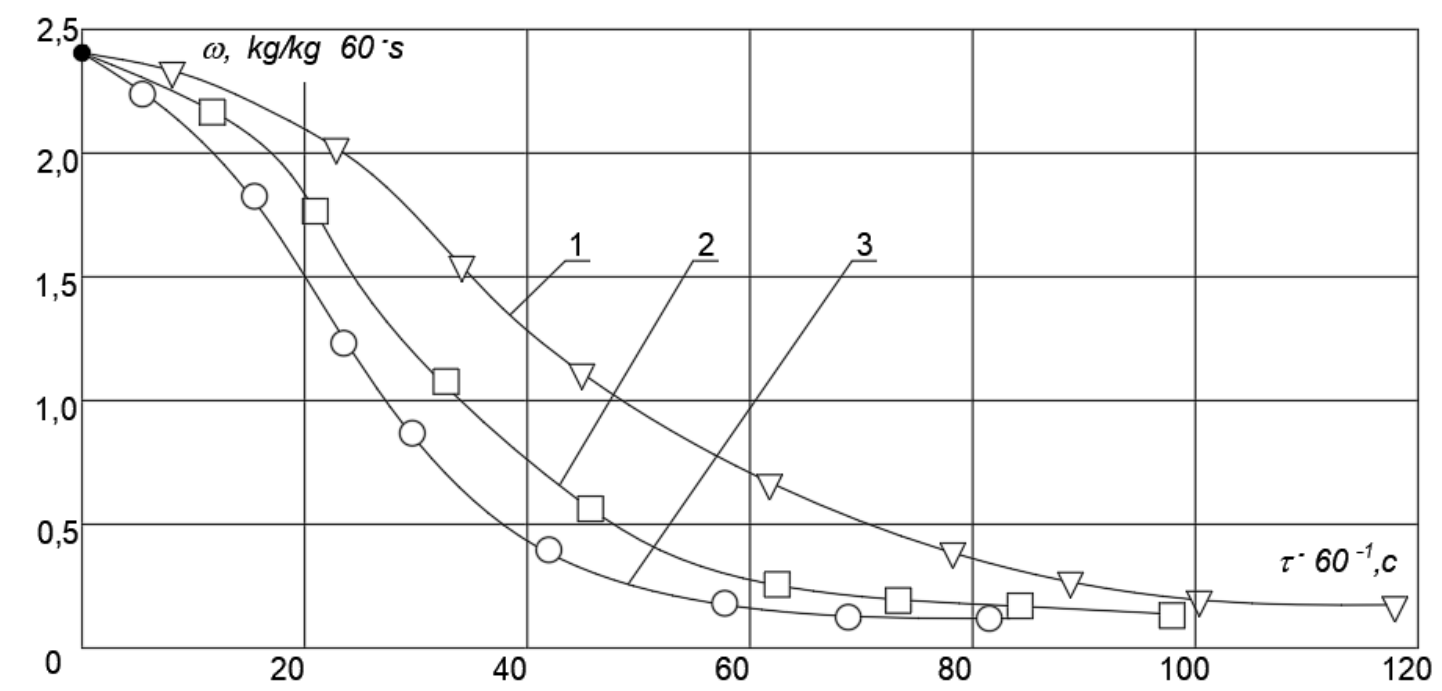

Fig. 1. Kinetics of moisture content at drying carrot bogasse: 1 - mode $1 ; 2-$ mode $2 ; 3$ - mode 3

Fig.2. presents the results of the experiment of kinetics of the moisture content at drying beet bogasse at different drying parameters. Thus, drying bogasse at mode 3 continues 104 min and at mode 2 it continues $112 \mathrm{~min}$, but its duration at mode 1 is $146 \mathrm{~min}$ that is by $40 \%$ more than at mode 3 .

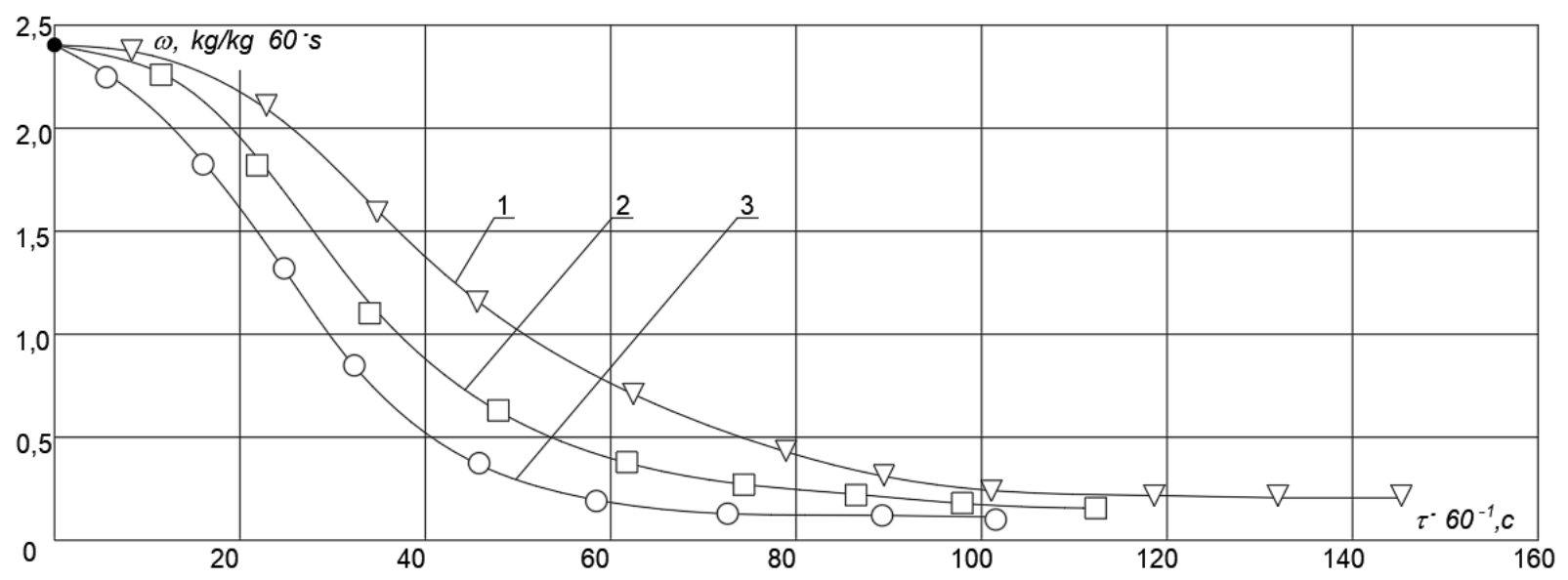

Fig. 2. Kinetics of moisture content at drying beet bogasse: 1 - mode $1 ; 2$ - mode 2;3-mode 3 
The conducted studies of kinetics of moisture content allowed to confirm the effectiveness of using vibration in drying processes of vegetable raw materials.

The analysis of a moisture content change with the time flow under conditions of different modes of drying bogasse proves the effectiveness of using vibration at realizing the process.

It must be also noted, that beet bossage at equal drying parameters are dried by $26 \%$ longer that is characterized by the physical-chemical composition of the raw material, namely by the content of pectin in beet that influences the process and binds moisture in the product.

\section{2. Study of colorimetric characteristics of obtained dried bogasse}

In all experiments the temperature in the working chamber was kept equal (heater temperature $106{ }^{\circ} \mathrm{C}$, vacuum in the working chamber $0,09 \mathrm{MPa}$ ), and the amplitude and frequency of vibration change corresponding to the experiments plan.

The research results, namely reflection spectrums depending on drying modes (Table 1) are presented on Fig. 3 (carrot bogasse) and Fig. 4 (beet bogasse).

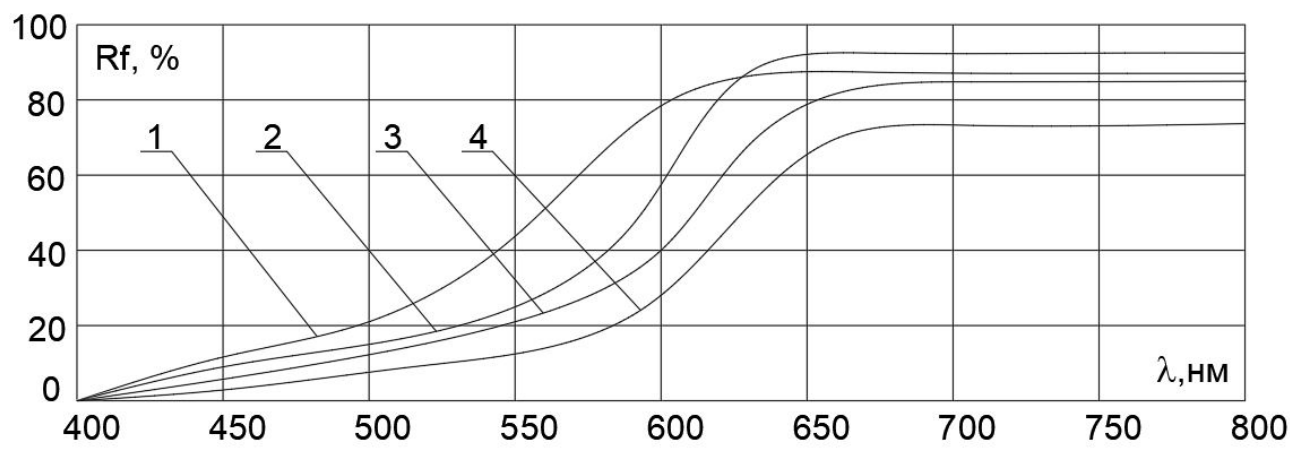

Fig. 3. Reflection spectrums of carrot bogasse depending on drying modes: 1 - mode 3;2 - mode 2; 3 - mode 1; 4 - bogasse after drying

The calculations, realized according to the research results, are presented in Table 2.

Analyzing the data of reflection spectrums, curve 1 has the little intensity in the diapason from 400 to $500 \mathrm{~nm}$, in the diapason from 500 to $600 \mathrm{~nm}$ the intensity grows that is characterized by the yellow-orange color, and curve 4 has another dynamics, thus, for example, the intensity grows in the diapason from 600 to $650 \mathrm{mn}$ that is characterized by the red-orange color. The results of curves 2 and 3 also demonstrated that in the diapason from 400 to $550 \mathrm{~nm}$ the intensity is minimal, and in the diapason from 550 to $650 \mathrm{~nm}$ it grows that is characterized by the orange color of samples.

Table 2

Colorimetric estimation of the quality of carrot bogasse depending on drying technological parameters

\begin{tabular}{ccccc}
\hline Raw material & $\begin{array}{c}\text { Carrot bogasse be- } \\
\text { fore drying }\end{array}$ & $\begin{array}{c}\text { Dried carrot bogasse } \\
\text { at mode No. 1 }\end{array}$ & $\begin{array}{c}\text { Dried carrot bogasse } \\
\text { at mode No. 2 }\end{array}$ & $\begin{array}{c}\text { Dried carrot bogasse } \\
\text { at mode No. 3 }\end{array}$ \\
\hline Dominating wave length, nm & 581,6 & 575,2 & 579,4 & 580,3 \\
Tone pureness & 85,67 & 76,97 & 80,31 & 43,84 \\
Brightness & 45,8689 & 43,5827 & 44,4144 & Orange
\end{tabular}


The growth of reflection intensity in the red-orange area of the visible spectrum characterizes its growth in the red component of light.

The dynamics of the wave length in the orange area of the visible spectrum is increased, and the color share grows that indicates the growth of the contribution of the orange component of the spectrum. Thus, mode 3 is optimal according to the obtained results.

The data of reflection spectrums are presented on Fig. 4 Curve 1 has a little intensity in the diapason from 400 to $450 \mathrm{~nm}$, and in one from 450 to $650 \mathrm{~nm}$ the intensity grows that is characterized by the yellow-red color. Thus, the results of curves 2 and 3 demonstrated that in the diapason from 550 to $700 \mathrm{~nm}$ the intensity grows that is characterized by the red-orange color of samples. Curve 4 has another dynamics, thus, for example, the intensity is minimal in the diapason from 400 to $650 \mathrm{~nm}$, and grows in one from 650 to $750 \mathrm{~nm}$ that is characterized by the saturated red color of samples.

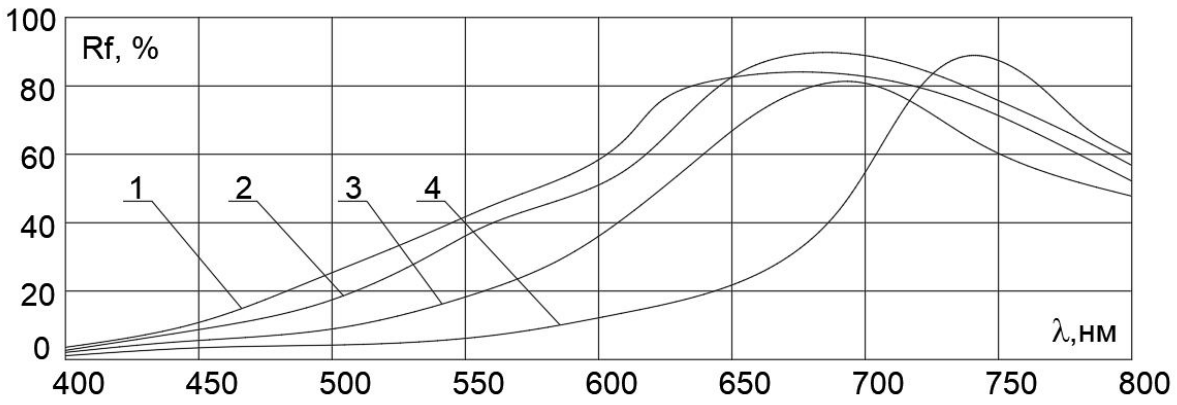

Fig. 4. Reflection spectrums of beet bogasse depending on drying modes:

1 - mode 3;2 - mode 2; 3 - mode 1, 4- bogasse before drying

The calculations, realized according to the research results of Fig. 4, are presented in Table 3.

Table 3

Colorimetric estimation of the quality of beet bogasse depending on drying technological parameters

\begin{tabular}{ccccc}
\hline Raw material & $\begin{array}{c}\text { Beet bogasse before } \\
\text { drying }\end{array}$ & $\begin{array}{c}\text { Dried Beet bogasse } \\
\text { at mode No. 1 }\end{array}$ & $\begin{array}{c}\text { Dried Beet bogasse } \\
\text { at mode No. 2 }\end{array}$ & $\begin{array}{c}\text { Dried Beet bogasse } \\
\text { at mode No.3 }\end{array}$ \\
\hline Dominating wave length, nm & 619,6 & 591,3 & 599,4 & 607,2 \\
Tone pureness & 58,10 & 69,58 & 76,11 & 86,11 \\
Brightness & 30,19 & 40,65 & 42,68 & 46,92 \\
Spectral color (dominating tone) & Red & Yellow-orange & Orange & Red-orange
\end{tabular}

The reflection intensity growth in the red area of the visible spectrum characterizes its growth in the red component of light. The dynamics of the wave length in the red area of the visible spectrum is increased (from $650 \mathrm{~nm}$ to $800 \mathrm{~nm}$ ), and the color share grows that indicates the growth of the contribution of the red component of the spectrum. Thus, mode 3 is optimal according to the obtained results.

It proves that qualitative, namely colorometric, characteristics of dried bossage depend on drying parameters, and the use of vibration at the drying process increases the main qualitative characteristics of obtained concentrates, namely, the tone saturation and color pureness.

\section{3. Results of studying the influence of main technological drying parameters on the} quality of dried bogasse

Fig. 5, 6 demonstrate, how the processing duration and drying modes influence organoleptic parameters of the obtained dried bogasse. Photos are presented in two variants, samples with the best outlook and ones with the worst one. 
As a result of the conducted theoretical and experimental studies, it was proved, that drying parameters essentially influence the process duration and quality parameters of the obtained concentrated products.

The optimal vibration mode for vibration-vacuum drying is established at pressure in the working chamber $0,09 \mathrm{MPa}$ : vibration amplitude $\mathrm{A}=0,005 \mathrm{~m}$, vibration frequency $\mathrm{f}=8 \mathrm{~Hz}$. At that the drying duration is $82 \mathrm{~min}$ and $104 \mathrm{~min}$ for carrot and beet bogasse, respectively.

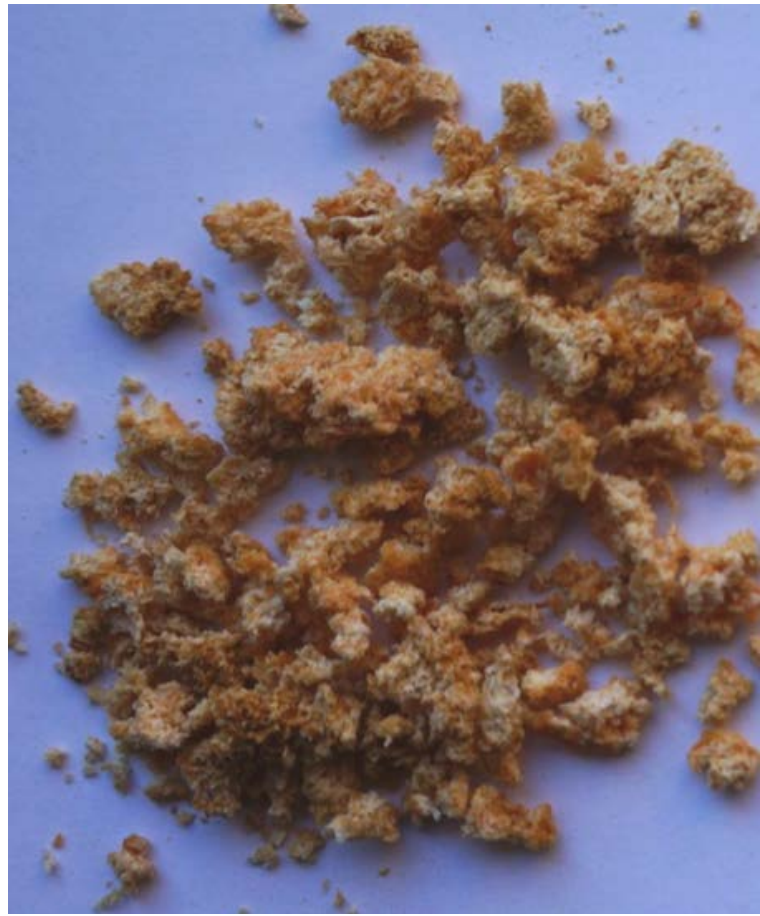

$a$

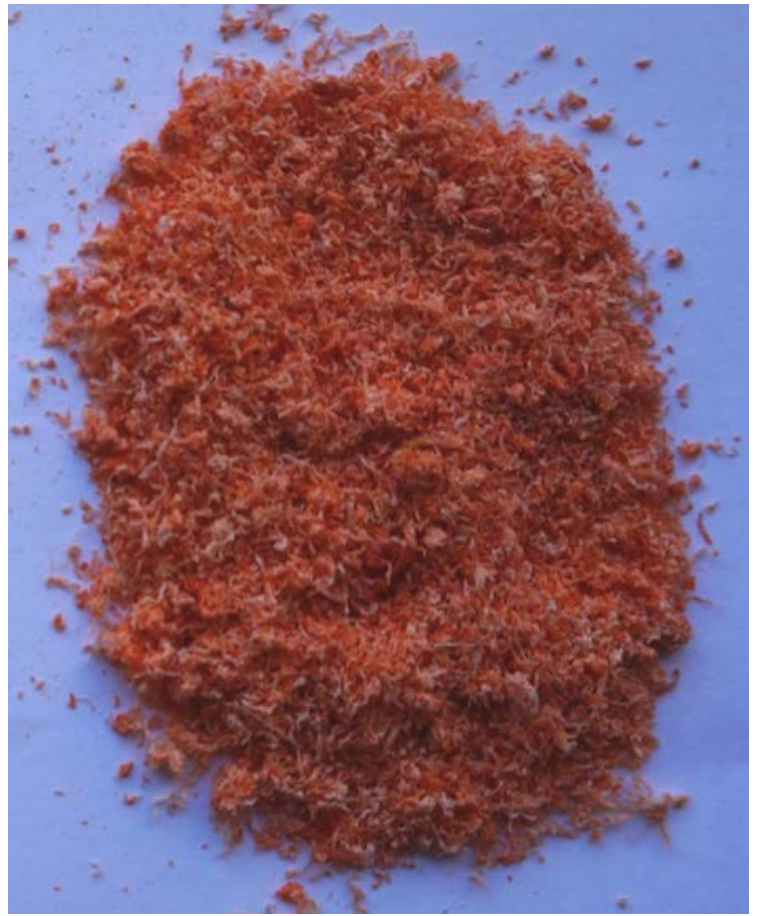

Fig. 5. Carrot bogasse, dried at different drying modes: $a$-mode $1 ; b$-mode 3 .

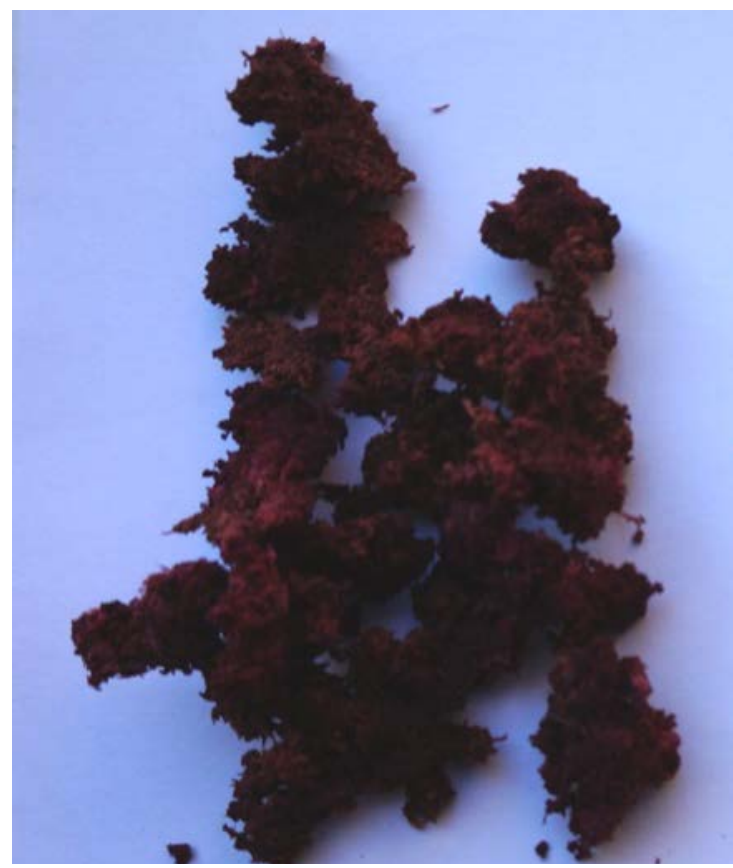

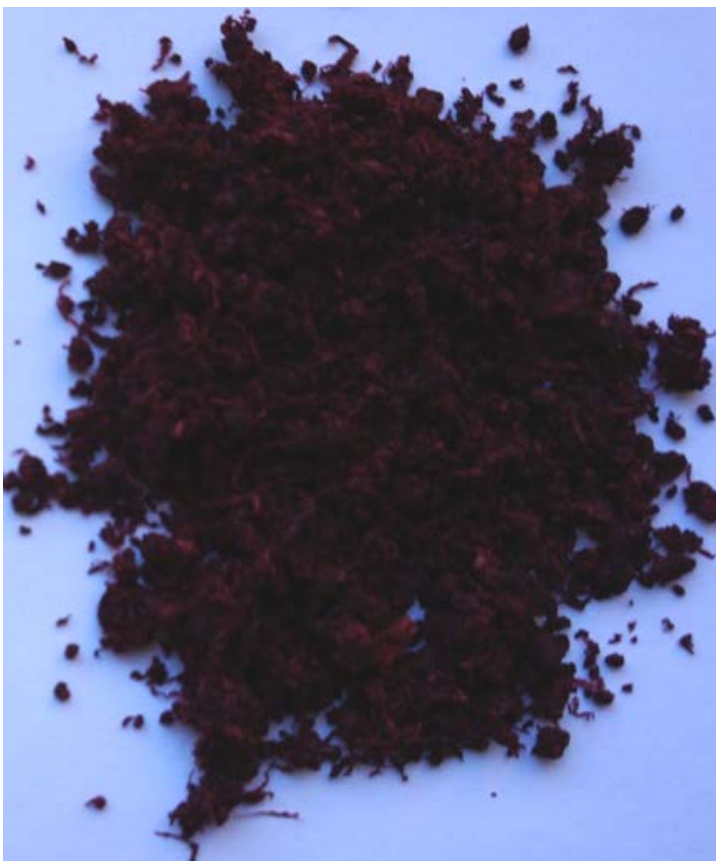

$b$

Fig. 6. Beet bogasse, dried at different drying modes: $a$-mode $1 ; b$-mode 3 


\section{Conclusions}

As a result of the conducted work, there were studied quality characteristics of dried carrot and beet bogasse that allowed to determine the dependence between color parameters of a dried product (tone saturation, color pureness) on working modes of the vibration vacuum drier (amplitude, frequency). Based on the result of studying colorimetric characteristics, obtained by reflection spectroscopy, it was proved that the use of vibration in the drying process essentially shortens the dehydration process duration that favors conservation of quality characteristics. It was established, that modes of technological processing influence deviation of values of a dominating wave length and brightness of dried bogasse from ones of these parameters for control samples. The determined color characteristics gave a possibility to establish that at thermal processing it is very important to decrease the raw material processing duration and temperature.

A shortcoming of the studies of quality parameters may be their narrow diapason. The quality of products of vegetable raw materials may be studied in the direction of determining vitamins and macroelements.

The further development of studies of the influence of technological parameters of the drier's work on the ready product's quality may be in changing a heater in the vibration vacuum drier, for example, for ir-heaters and in investigating their influence on quality parameters of processed products, establishing connections between certain quality criteria and processing regimes.

Thus, the offered method of drying bogasse in the developed drier allows to improve the quality of obtained dried product essentially and to use them as improvers of culinary, bakery, confectionary products and for healthy nutrition.

\section{References}

[1] Potapov, V., Plevako, V., Kostenko, S., Pedorich, I., Arkhipova, V. (2016). Physical and Analytical Modeling of Infrared Frying in ARJM-0.07-1 Apparatus. Industrial Technology and Engineering, 3 (20), 54-61.

[2] Nistor, O.-V., Seremet (Ceclu), L., Andronoiu, D. G., Rudi, L., Botez, E. (2017). Influence of different drying methods on the physicochemical properties of red beetroot ( Beta vulgaris L. var. Cylindra ). Food Chemistry, 236, 59-67. doi: https://doi.org/10.1016/j.foodchem.2017.04.129

[3] Snezhkin, Yu. F., Shapar', R. A. (2006). Osobennosti processa sushki pektinosoderzhashchih materialov. Promyshlennaya teplotekhnika, 28 (3), 25-27.

[4] Demarchi, S. M., Torrez Irigoyen, R. M., Giner, S. A. (2018). Vacuum drying of rosehip leathers: Modelling of coupled moisture content and temperature curves as a function of time with simultaneous time-varying ascorbic acid retention. Journal of Food Engineering, 233, 9-16. doi: https:// doi.org/10.1016/j.jfoodeng.2018.03.027

[5] Bizmark, N., Mostoufi, N., Sotudeh-Gharebagh, R., Ehsani, H. (2010). Sequential modeling of fluidized bed paddy dryer. Journal of Food Engineering, 101 (3), 303-308. doi: https://doi.org/10.1016/ j.jfoodeng.2010.07.015

[6] Shishic'kiy, Yu. I., Golubyatnikov, E. I. (2011). Tekhnika sushki pektinosoderzhashchego rastitel'nogo syr'ya - svekolichnogo zhoma. Voprosy sovremennoy nauki i praktiki Universitet im. V. I. Vernadskogo, 1 (32), 391-402.

[7] Malezhyk, I. F., Levkivska, T. M., Bezusov, A. T. (2009). Doslidzhennia kinetyky sushinnia morkvianykh vychavok za dopomohoiu infrachervonoho vyprominiuvannia. Naukovi pratsi ONAKhT, 2 (35), 107-110.

[8] Shershnov, H., Sardarov, A., Maiak, O. (2018). Rozrobka konstruktsiyi vibratsiynoi vakuumnoi susharky bezperervnoi dii dlia optymizatsiyi protsesu sushinnia roslynnoi syrovyny. Materialy 84 mizhnarodnoi naukovoi konferentsiyi molodykh uchenykh, aspirantiv i studentiv "Naukovi zdobutky molodi - vyrishenniu problem kharchuvannia liudstva u XXI stolitti”. Kyiv: NUKhT, 204-205. 
[9] Maiak, O. A., Sardarov, A. M., Shershnov, H. H. (2016). Vybir parametriv vibroobrobky suspenziyi roslynnoho pokhodzhennia za umov sushinnia. Materialy mizhnarodnoi naukovo-praktychnoi konferentsii «Udoskonalennia protsesiv i obladnannia - zaporuka innovatsiynoho rozvytku kharchovoi promyslovosti» Prysviachena 65-richchiu kafedry protsesiv i aparativ kharchovykh vyrobnytstv NUKhT Kyiv: NUKhT, 60-61.

[10] Kiptela, L. V., Zahorulko, A. M., Zahorulko, O. Ye. et. al. (2017). Analiz isnuiuchykh sposobiv vyznachennia yakosti produktiv kharchuvannia za kolorom. Prohresyvni tekhnika ta tekhnolohii kharchovykh vyrobnytstv restorannoho hospodarstva i torhivli, 2 (26), 354-363.

[11] Dubinina, A., Selyutina, G., Letuta, T., Shcherbakova, T., Afanasieva, V. (2017). Effect of the parameters of rhubarb and gooseberry treatment on the formation of color. Eastern-European Journal of Enterprise Technologies, 6 (11 (90)), 66-71. doi: https://doi.org/10.15587/1729-4061.2017.117253 